\title{
Prescribing in Pregnancy
}

\section{Treatment of rheumatic diseases}

\section{A BYRON}

Musculoskeletal disorders are common, and conditions such as low back pain and carpal tunnel syndrome may require treatment during pregnancy. Rheumatic conditions are more common in women, with the peak prevalence of rheumatoid arthritis and systemic lupus erythematosus occurring in women of childbearing age. Antirheumatic drugs are, therefore, often required for women of childbearing age. ${ }^{1}$

Table I lists the groups of drugs prescribed for rheumatic conditions. Analgesics and non-steroidal anti-inflammatory drugs are most commonly prescribed, some of which-for example, ibuprofen-are now available without prescription. Several reviews discuss the effects of these drugs during pregnancy and lactation ${ }^{2-4}$

TABLE I-Antirheumatic drugs

\begin{tabular}{lll}
\hline Drug group & Condition treated \\
\hline Analgesics & $\begin{array}{l}\text { Soft tissue lesions } \\
\text { Inflammatory arthritides } \\
\text { Osteoarthritis } \\
\text { Systemic lupus erythematosus } \\
\text { Antimalarial drugs }\end{array}$ & $\begin{array}{l}\text { Rheumatoid arthritis } \\
\text { Rheumatoid arthritis } \\
\text { Ankylosing spondylitis }\end{array}$ \\
Sulphasalazine & $\begin{array}{l}\text { Severe, persistent rheumatoid arthritis } \\
\text { Psoriatic arthritis }\end{array}$ \\
Gold salts & $\begin{array}{l}\text { Systemic lupus erythematosus } \\
\text { Penicillamine }\end{array}$ Rheumatoid arthritis (infrequently) \\
Corticosteroids & $\begin{array}{l}\text { Other connective tissue diseases } \\
\text { Systemic lupus erythematosus } \\
\text { Severe unremitting rheumatoid arthritis } \\
\text { Other connective tissue diseases }\end{array}$ \\
\hline
\end{tabular}

\section{Non-steroidal anti-inflammatory drugs}

TERATOGENICITY

Studies in animals have linked a variety of skeletal and craniovertebral abnormalities with ingestion of large doses of salicylates during pregnancy. In humans several retrospective surveys have shown that significantly more mothers of malformed infants took salicylates regularly during pregnancy than mothers of normal infants. ${ }^{5}$ In these studies, however, factors such as the reason for taking salicylates, general health and nutrition of the mothers, and incidence of defects in the families of the malformed children were not always investigated. Three prospective studies have not shown a teratogenic effect of aspirin ${ }^{6-8}$ The largest study, the Perinatal Collaborative Project of the United States of America, found that malformation rates were similar in the children of 35418 women not exposed to aspirin, 9736 with intermediate exposure, and 5128 women heavily exposed during the first four months of pregnancy. ${ }^{8}$

Nuffield Department of Gynaecology and Obstetrics, John Radcliffe Hospital, Oxford OX3 9DU

M A BYRON, MRCP, senior registrar in rheumatology

This series is edited by Dr P C Rubin.
Even in women identified as habitual aspirin users the prevalence of is congenital malformation was not significantly increased.' Overall, therefore, the evidence suggests that salicylates used in recommended doses are unlikely to produce fetal malformations.

Indomethacin is associated with teratogenicity in animals, but the link with human malformation is tenuous. ${ }^{26}$ Sulindac, diflunisal, and piroxicam have not been found to be teratogenic in animals, whereas azapropazone and diclofenac have, though at doses greater than those used in humans..$^{2910}$ No information is available for the fenamates and tolmetin. Studies in animals have found no evidence of teratogenicity with the commonly prescribed propionic acid derivatives such as ketoprofen, ibuprofen, flurbiprofen, and naproxen. ${ }^{9}$

\section{EFFECTS ON FETAL GROWTH}

A survey from Sydney showed that long term ingestion of aspirin was associated with an increased incidence of stillbirth and reduced birth weight compared with that of controls. ${ }^{7}$ Most of the aspirin preparations ingested, however, were compounds containing substances such as phenacetin and caffeine and were taken in large doses. Data from the United States showed no significant effect of aspirin ingestion on birth weight or perinatal mortality. ${ }^{11}$ There is no convincing evidence that indomethacin or other non-steroidal anti-inflammatory agents affect fetal growth.

\section{EFFECTS MEDIATED THROUGH INHIBITION OF PROSTAGLANDIN SYNTHESIS}

Table II summarises the conditions associated with the use of inhibitors of prostaglandin synthesis in pregnancy.

\begin{tabular}{l} 
TABLE II-Conditions associated with use of \\
inhibitors of prostaglandin synthesis in pregnancy \\
\hline Effects on mother \\
Prolongation of pregnancy \\
Prolongation of labour \\
Increased blood loss both before and after birth \\
Anaemia \\
Pre-eclamptic toxaemia \\
Effects on fetus and neonate \\
Haemostatic abnormalities \\
Increased incidence of intracranial haemorrhage \\
Premature closure of ductus arteriosus \\
Persistent pulmonary hypertension \\
\hline
\end{tabular}

A retrospective study of women with musculoskeletal disorders showed that those who took more than $3.25 \mathrm{~g}$ of aspirin a day during $\mathbb{D}$ the last six months of pregnancy had a significantly longer gestation, longer labour, and greater blood loss at delivery than women who had not taken aspirin. ${ }^{12}$ Collins and Turner also found an increased incidence of anaemia, antepartum haemorrhage, and pre-eclampsia in women who took aspirin for long periods. "Haemostatic abnormalities and a higher incidence of intracranial haemorrhage 
have been found in neonates whose mothers ingested aspirin within a few days of delivery..$^{13}$

In the fetus prostaglandin $E_{1}$ causes relaxation of systemic and pulmonary vessels as well as the ductus arteriosus, and $90 \%$ of blood ejected by the right ventricle passes through the ductus arteriosus to the descending aorta. ${ }^{15}$ Administration of single doses of an antiinflammatory agent to a variety of animals results in reversible constriction of the ductus arteriosus and a substantial increase in pulmonary artery pressure in the fetus. Long term exposure to antiinflammatory agents in animals and humans is associated with increased amounts of pulmonary artery smooth muscle which results in persistent pulmonary hypertension in the newborn infant, with or without premature closure of the ductus arteriosus. ${ }^{16}$

Neonatal respiratory complications attributed to the use of nonsteroidal anti-inflammatory drugs in the treatment of premature labour support this association. ${ }^{718}$ Since other studies, however, have found no increase in fetal mortality when premature labour was suppressed with non-steroidal anti-inflammatory drugs, ${ }^{19}$ it is likely that the dose and duration of administration of the drug, the gestational age of the fetus at the time of exposure, and the time between the last dose of the drug and the birth of the infant are important factors. Infants born to mothers receiving long term antiinflammatory treatment are probably most at risk.

\section{BREAST FEEDING}

Because non-steroidal anti-inflammatory drugs are weak acids they do not achieve high concentrations in milk. All manufacturers state in their drug information that these drugs should not be used in lactating women. This caution is based on lack of specific information rather than known adverse reactions, and the benefit associated with breast feeding may outweigh the risks of a carefully chosen drug. The appropriate drugs should have a short elimination half life and metabolites which are inert or rapidly eliminated, or both. Hydroxy or methyl metabolites are relatively stable in the infant's stomach whereas glucuronide derivatives may be cleaved, releasing active metabolites. ${ }^{3}$ Table III shows the suitability of various drugs. Reported side effects are uncommon, but plasma salicylate concentrations of $24 \mathrm{mg} / \mathrm{dl}$ were found in a breast fed child with metabolic acidosis whose mother was taking $2.4 \mathrm{~g}$ aspirin a day, and a grand mal fit occurred in a child whose mother was taking indomethacin. ${ }^{3}$

\section{Antimalarial drugs}

Chloroquine salts (4-aminoquinolone compounds) cross the placenta and rapidly accumulate in the fetal uveal tract of mice. ${ }^{20}$ Teratogenic effects of these substances are probably dose related, and experience from countries where malaria is endemic affirms the safety of weekly prophylactic doses in pregnancy. ${ }^{21}$ Exposure during the first trimester to the doses required to treat rheumatic diseases, however, has resulted in fetal sensorineural hearing loss. ${ }^{22}$

\section{BREAST FEEDING}

Both chloroquine and hydroxychloroquine have been found in small quantities in human milk. Despite their widespread use by lactating women for malaria prophylaxis and the lack of reported adverse effects in breast fed infants, the daily doses required for treatment of chronic rheumatic diseases may cause retinal damage, which is difficult to monitor in childen of this age. Their use in lactating women is, therefore, not recommended.

\section{Sulphasalazine}

Sulphasalazine is increasingly used as a second line treatment in rheumatoid arthritis. Experience with sulphasalazine in the treatment of inflammatory bowel disease has shown that it is safe to use throughout pregnancy and lactation. ${ }^{4}$ As it impairs absorption of folic acid, supplementation is recommended during pregnancy.

\section{Gold salts}

Both gold thiomalate and auranofin, an oral gold preparation, have proved teratogenic in animals. Gold has been found in the liver and kidneys of an aborted human fetus, and there are reports of possible teratogenic effects. ${ }^{23}{ }^{24}$ Two studies, however, report the safe use of gold during pregnancy, ${ }^{2526}$ and therapeutic gold concentrations have been detected in cord blood without evidence of congenital defects. ${ }^{27}$

\section{BREAST FEEDING}

Trace amounts of aurothioglucose have been detected in the milk of lactating women, and gold has been found bound to the red blood cells of breast fed infants. ${ }^{3}$ The theoretical possibility of toxicity precludes its use during breast feeding.

\section{Penicillamine}

The chelating agent penicillamine (dimethylcysteine) is used for treating Wilson's disease, cystinuria, and rheumatoid arthritis. Its use in pregnancy has been associated with the development of a generalised connective tissue defect, similar to that of EhlersDanlos syndrome, in three babies. ${ }^{28-30}$ Two died, but in the third the cutis laxa was reversible. Many normal children, however, have been born to mothers taking penicillamine for Wilson's disease, ${ }^{31} 32$ and it was proposed that in this disease the fetus was protected from the effects of penicillamine by the excessive maternal pool of copper. In another survey, however, one ventricular septal defect was the only abnormality reported in 27 pregnancies in patients with rheumatoid arthritis and cystinuria. ${ }^{33}$

\section{BREAST FEEDING}

Penicillamine is extensively protein bound and has a short half life, so only small amounts should be present in breast milk. No specific investigations in lactation have, however, been carried out. The potential toxicity makes its use hazardous.

\section{Corticosteroids}

The pharmacology of corticosteroids and potential effects on the fetus are discussed in the article on treatment of asthma. In

TABLE III-Antirheumatic drug treatment and lactation

\begin{tabular}{|c|c|}
\hline Drugs suitable for use during lactation & Reasons for suitability \\
\hline $\begin{array}{l}\text { Non-steroidal anti-inflammatory drugs: } \\
\text { Ibuprofen } \\
\text { Flurbiprofen } \\
\text { Diclofenac } \\
\text { Mefenamic acid }\end{array}$ & $\begin{array}{l}\text { Small quantities found in milk } \\
\text { Short elimination half life } \\
\text { Inert metabolites }\end{array}$ \\
\hline $\begin{array}{l}\text { Sulphasalazine } \\
\text { Corticosteroids }\end{array}$ & See text \\
\hline Drugs not suitable for use during lactation & Reasons for unsuitability \\
\hline $\begin{array}{l}\text { Non-steroidal anti-inflammatory drugs: } \\
\text { Salicylates } \\
\text { Fenoprofen } \\
\text { Ketoprofen }\end{array}$ & Glucuronide metabolites \\
\hline $\begin{array}{l}\text { Naproxen } \\
\text { Piroxicam } \\
\text { Diflunisal } \\
\text { Flufenamic acid } \\
\text { Tolmetin-Na } \\
\text { Azapropazone }\end{array}$ & Long half life \\
\hline $\begin{array}{l}\text { Fenbufen } \\
\text { Sulindac }\end{array}$ & Active metabolites \\
\hline Indomethacin & $\begin{array}{l}\text { Variable half-life; enterohepatic circulation } \\
\text { of metabolites }\end{array}$ \\
\hline Antimalarial drugs & Risk of retinal damage \\
\hline $\begin{array}{l}\text { Gold salts } \\
\text { Penicillamine }\end{array}$ & Potential renal and bone marrow toxicity \\
\hline
\end{tabular}


two studies of pregnancy associated with corticosteroid treatment 37 pregnancies in 24 patients with rheumatic diseases were evaluated. ${ }^{34} 35$ Although five pregnancies resulted in abortion and four in fetal death, this was in a group of patients at high risk of fetal loss. Length of gestation and birth weight were within normal limits and a few minor fetal abnormalities were considered unrelated to steroid treatment in the mother. Both studies emphasised the importance of giving the mother additional corticosteroids during delivery and the rarity of fetal adrenocortical insufficiency.

\section{BREAST FEEDING}

In the doses most commonly used for treating rheumatic diseases ( $15 \mathrm{mg}$ of prednisolone a day or less) there is little chance of an infant receiving appreciable amounts of prednisolone in breast milk. ${ }^{36}$

\section{Cytotoxic drugs}

Alkylating agents and antimetabolites may be teratogenic and mutagenic, and even if used after the first trimester of pregnancy the fetus is susceptible to bone marrow depression, infection, and haemorrhage. ${ }^{37}$ Azathioprine is the cytotoxic agent most commonly used in rheumatic disorders. In a study of 125 pregnancies in renal transplant recipients taking both azathioprine and prednisone only one infant showed a congenital abnormality, though a number had lymphopenia, growth retardation, and an increase in chromosomal breakage ${ }^{38}$ Results of long term follow up studies in these children are not available. The risk of lymphoproliferative and gonadal disorders would be likely to cause concern.

\section{BREAST FEEDING}

Many cytotoxic drugs are found in appreciable amounts in human milk, and the risk to the infant would outweigh any benefits of breast feeding.

\section{Guidelines for antirheumatic treatment in pregnancy}

Adequate explanations of the possible risks of any proposed treatment, with appropriate advice on contraception, are essential when treating women of childbearing age. The use of drugs that pose the least threat to the fetus will minimise anxiety should pregnancy occur. In women with established rheumatic diseases it is important to appreciate that without the use of agents which suppress the disease pregnancy may not have occurred or may not have been carried to term. Adequate control of the disease may also enable a woman to feel capable of bearing and raising children. There is a good chance of remission of rheumatoid arthritis during pregnancy, though aggressive treatment may continue to be necessary in systemic lupus erythematosus. ${ }^{2}$

\section{NON-STEROIDAL ANTI-INFLAMMATORY AGENTS}

Drug action is a function of concentration and time. To minimise the effects on the fetus drugs with a short elimination half life and inactive metabolites-for example, ibuprofen, flurbiprofen, and ketoprofen-should be used at the maximum tolerated dosage interval. The most potent inhibitors of prostaglandin synthesis, such as salicylates and indomethacin, should be avoided throughout pregnancy, if possible, and certainly during the last trimester. Well motivated women with moderate symptoms may be managed with simple analgesics, paracetamol being the drug of choice.

\section{DRUGS THAT MODIFY RHEUMATIC DISEASE}

Only a small proportion of women require disease modifying drugs. Antimalarial drugs are contraindicated in pregnancy or lactation, whereas sulphasalazine appears to be safe, though folate supplements should be given. Treatment with gold and penicillamine should not be started during pregnancy, and these drugs should not be used by breast feeding women. If a woman becomes pregnant while taking these drugs gold can be continued at the longest possible dosage interval and penicillamine should be slowly reduced or withdrawn. Pyroxidine supplements are recommended as penicillamine may deplete maternal stores. ${ }^{3}$ Careful consideration should be given to the use of cytotoxic agents in pregnancy. Although azathioprine appears to be relatively safe, long term follow up data are not yet available. Corticosteroids in the doses required to treat rheumatic conditions seem to be safe in pregnancy and lactation. Additional doses are needed to cover delivery. Fetal adrenal insufficiency is rare.

\section{References}

1 Hill RM. Drugs ingested by pregnant women. Clin Pharmacol Ther 1973;14:654-9.

2 Needs CJ, Brooks PM. Antirheumatic medication in pregnancy. Br $\mathcal{J}$ Rheumatol 1985;24:282-90. Needs CJ, Brooks PM. Antirheumatic medication during lactation. Br $\mathcal{O}$ Rheumatol 1985;24: 291-7.

4 de Swiet M, ed. Medical disorders in obstetric practice. Oxford: Blackwell Scientific Publications, 1984.

5 Collins E. Maternal and fetal effects of acetaminophen and salicylates in pregnancy. Obstet Gynecol 1981;58:(suppl 5):57-62.

6 Buckfield P. Major congenital faults in newborn infants: a pilot study in New Zealand. NZ Med $\mathcal{f}$ 1973;78:195-204.

7 Turner G, Collins E. Fetal effects of regular salicylate ingestion in pregnancy. Lancet 1975;ii: $338-40$.

8 Slone D, Heinonen O, Kaufman DW, Siskind V, Monson RR, Shapiro S. Aspirin and congenital malformations. Lancet 1976;i:1373-5.

9 Anti-rheumatic drugs. In: Huskisson EC, ed. Clinics in rheumatic diseases. London: W B Saunders, 1979;5:2.

10 Anti-rheumatic drugs II. In: Huskisson EC, ed. Clinics in rheumatic diseases. London: W B Saunders, 1980;6:3.

11 Shapiro S, Monson RR, Kaufman DW, Siskind V, Heinonen O, Slone D. Perinatal mortality and birth weight in relation to aspirin taken during pregnancy. Lancet 1976; i:1375-6.

12 Lewis RB, Shulman JD. Influence of acetylsalicylic acid, an inhibitor of prostaglandin synthesis, on the duration of human gestation and labour. Lancet 1973;ii:1159-61.

13 Rumack CM, Guggenheim MA, Rumack BH, Peterson RG, Johnson ML, Braithwaite WR. Neonatal intracranial hemorrhage and maternal use of aspirin. Obstet Gymecol 1981;58(suppl 5): 52-6.

14 Stuart MJ, Gross SJ, Elrad H, Graeber JE. Effects of acetylsalicylic-acid ingestion on maternal and neonatal hemostasis. N Engl f Med 1982;307:909-12.

15 Rudolph AM. The effects of non-steroidal anti-inflammatory compounds on fetal circulation and pulmonary function. Obstet Gynecol 1981;58(Suppl 5):63-7.

16 Levin DL, Mills LJ, Weinberg AG. Haemodynamic pulmonary vasculature and myocardial abnormalities secondary to pharmacologic constriction of fetus ductus arteriosus: a possible mechanism for persistent pulmonary hypertension and transient tricuspid insufficiency in the new born infant. Circulation 1979;60:360-4

17 Zuckerman $H$, Reiss V, Rubenstein I. Inhibition of human premature labour by indomethacin Obstet Gynecol 1974;44:787-9.

18 Wilkinson AR, Aynsley-Green A, Mitchell MD. Persistent pulmonary hypertension and abnormal prostaglandin $\mathrm{E}$ levels in preterm infants after maternal treatment with naproxen. Arch Dis Child 1979;54:942-5.

19 Wiquist N, Lundstrom V, Green K. Premature labour and indomethacin. Prostaglandins 1975;10:515-26.

20 Ullberg S, Lindquist N, Sjostrand S. Accumulation of chorio-retinotoxic drugs in the foetal eye. Nature 1970;227:1257-8.

21 Lewis R, Lauersen NH, Birnbaum S. Malaria associated with pregnancy. Obstet Gynecol 1973;42:696-700.

22 Hart CW, Naunton RF. The ototoxicity of chloroquine phosphate. Arch Otolaryngol 1964;80: 407-12.

23 Rocker I, Henderson WJ. Transfer of gold from mother to fetus. Lancet 1976;ii: 1246.

24 Rogers JG, Anderson RMcD, Chow CW. Possible teratogenic effects of gold. Aust Paediatr $\mathcal{J}$ 1980;16:195-8.

25 Stern L. Drug therapy in the perinatal period. In: Morselli PL, Garattini S, Sereni S, eds. Basic and therapeutic aspects of perinatal pharmacology. New York: Raven Press, 1975:7-12.

26 Zvaifler NJ. Gold and anti-malarial therapy. In: McCarty DJ, ed. Arthritis and allied conditions. Th ed. Philadelphia: Lea and Febiger, 1979:357.

27 Cohen DL, Orzd J, Taylor A. Infants of mothers receiving gold therapy. Arthritis Rheum $1981 ; 24: 104-5$.

28 Mjolnerod OK, Dommerud SA, Rasmussen K, Gjeruldsen ST. Congenital connective tissue defect probably due to d-penicillamine treatment in pregnancy. Lancet 1971;i:673-5.

29 Solomon L, Abrams G, Dinner M, Berman L. Neonatal abnormalities associated with d-penicillamine treatment during pregnancy. $N$ Engl f Med 1977;296:54-5.

30 Linares A, Zarranz JJ, Rodriguez-Alarcon J, Diaz-Perez JL. Reversible cutis laxa due to maternal d-penicillamine therapy. Lancet 1979;ii:43.

31 Scheinberg IH, Sternlieb I. Pregnancy in penicillamine treated patients with Wilson's disease. N Engl f Med 1975;293:1300-2.

32 Walshe JM. Pregnancy in Wilson's disease. Qf Med 1977;46:73-83.

33 Lyle WH. Penicillamine in pregnancy. Lancet 1978;i:606-7.

34 Popert AJ. Pregnancy and adreno cortical hormones, some aspects of their interactions in rheumatic diseases. Br Med f 1962;i:967-72.

35 Yackel DB, Kempers RD, McConahey WM. Adrenocorticosteroid therapy in pregnancy. Am $\mathcal{J}$ Obstet Gynecol 1966;96:985-9.

36 McKenzie SA, Selley JA, Agnew JE. Secretion of prednisolone into breast milk. Arch Dis Child 1975;50:894-6.

37 Barber HRK. Fetal and neonatal effects of cytotoxic agents. Obstet Gynecol 1981;58:(suppl 5): 41-7.

38 Nolan GH, Sweet RL, Laros RK. Renal cadaver transplantation followed by successful pregnancies. Obstet Gynecol 1974;43:732-9.

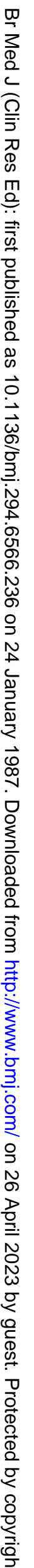

